\title{
Influence of ground fires on the grass cover of birch forests of the Eltsovsky discrit of the Altai region
}

\author{
Galina Sokolova* \\ Altai State University, Lenina str., 101, Barnaul, 656041, Russia
}

\begin{abstract}
The article contains the results of research of influence of surface fire on the vegetation of birch forests in the Eltsovsky district of the Altai region. Changes in species composition and structure of birch stands after fires on the slopes of different exposures are considered. Groups of species were identified depending on the reaction to the action of ground fires.
\end{abstract}

The study area covers the belt of birch forests and steppe meadows. It is characterized by hilly-rolling relief, strongly dissected by a network of valleys and beams. Birch forests, sometimes with an aspen admixture, on dark gray forest soils are the main type of vegetation. Steppe meadows on podzolized chernozem are developed on the watersheds, and on the slopes of the southern exposition there are areas of meadow steppes on leached chernozem.

Currently, the forest area has been greatly reduced due to clearings and the allocation of vacant land for arable land. The remaining birch forests are mainly located on the slopes of valleys and beams. For the release of agricultural land from plant residues often use their direct combustion. Agricultural burning spreads beyond arable land, leading to outbreak fires in forest ecosystems [1-3].

The aim of our work was to study the influence of low-level fires on the grass cover of birch forests in the Eltsovsky district of the Altai region. We carried out a reconnaissance survey of the area with the allocation of 10 control sites, reflecting the nature of the distribution and structure of birch forests, and 10 sites where forest ecosystems were exposed to low-level fires. Standard geobotanical releves of vegetation have been carried out at all sites [4]. Several plots, where the influence of ground fires on the grass cover and the dynamics of overgrowth of burning were being traced, were laid out on the slopes of different exposures.

There are two types of birch forests in the study area: birch forests with the predominance of meadow and meadow-steppe species growing on the southern slopes, and birch forests with large grass species typical of blackwood forests, and the northern exposure.

Such species as Caragana arborescens Lam., Rosa majalis Herrm., R. acicularis Lindl., Spiraea media F. Schmidt, etc. can be found in the undergrowth of birch forests. The first type of the grass cover of birch trees (whose height is $50-80 \mathrm{~cm}$ ) is represented by the

\footnotetext{
* Corresponding author: sokolova-gg@mail.ru
} 
following species: Dactylis glomerata L., Calamagrostis arundinacea (L.) Roth, Trifolium lupinaster L., Bupleurum aureum Fisch. ex Hoffm., Vicia unijuga A.Br., Polygonatum odoratum (Mill.) Druce, Rubus saxatilis L., Crepis sibirica L., Pedicularis incinata Steph., Origanum vulgare L., Serratula coronata L., Phlomis tuberosa L., Pteridium aquilinum (L.) Kuhn, etc.

The second type of the grass cover of birch forests with an average height of 120-150 $\mathrm{cm}$ is characterized by the presence of Dactylis glomerata, Vicia sylvatica L., Crepis sibirica, Heracleum dissectum Ledeb., Pleurospermum urlense Hoffm., Cirsium heterophyllum (L.) Hill, Aconitum septentrionale Koelle, Euphorbia pilosa L., Pteridium aquilinum (L.) Kuhn [5].

The analysis of the species composition and structure of the grass cover of the birch forests of the Eltsovsky district showed that the grass stand of birch forests is represented by 108 species of grassy plants belonging to 38 families and 87 genera. They are characterized by an uneven distribution over the slopes of different exposures. The greatest species diversity of birch forest cover is observed on the slopes of the southern exposures (43 species), the smallest number of species (18.0) is a characteristic of the slopes of the northern exposures. The number of species on the eastern and western slopes averages 28 .

The total projective cover of birch stands on the slopes of the southern, eastern and western exposures averages $63.5 \%$, and on the slopes of the northern exposures $-33.7 \%$. The number of weed species ranges from 11.5 to $13.6 \%$ of the total number of species. This indicator is slightly different for the slopes of different exposures. The share of rare and endangered species in the herbage on the slopes of all exposures averages $4.2 \%$.

Such an indicator as the abundance of the species also varies depending on the exposure of the slope. Dactylis glomerata, Pteridium aquilinum, Aegopodium podagraria L. dominate on the slopes of the southern, eastern and western exposures. Angelica decurrens (Ledeb.) B. Fedtsch., Aegopodium podagraria, Dactylis glomerata, Pteridium aquilinum dominate on the slopes of the northern exposures.

Botanical analysis of the grass cover of birch forests has showed that forbs prevail on the slopes of all exposures. Grasses are more presented on the slopes of the eastern and southern exposures. The distribution of legumes and sedges goes on the slopes of all exposures in approximately the same way, which indicates good adaptive abilities of the species of these botanical groups.

Ecological analysis has revealed the prevalence of mesophytes on all slopes, their proportion ranging from 77.4 to $89.9 \%$. Group of mesohygrophytes falls out on the slopes of the southern exposure, since the hydrological conditions are not suitable for the representatives of this group. On the northern slopes the proportion of mesohygrophytes is maximum. Mesoxerophytes are present on the slopes of all exposures, but their share is higher on the western slopes.

The analysis of plant life forms revealed that perennial rhizomatous species prevail on the slopes of all exposures (96.7-97.8\%), the share of one- and two-year species is 2.2$3.3 \%$.

The study of the grassland of birch forests after fires showed that the species diversity of grass cover on the burns has decreased to 82 species belonging to 68 genera and 28 families. The tendency to reduce species diversity on the slopes of the western exposure is obvious. The greatest species diversity is typical of the slopes of the eastern and northern exposures, where the number of species has decreased only by $6 \%$, which indicates the best regenerative ability of the stand of birch forests in these conditions.

Fires in birch forests caused a qualitative change in the species composition of grassy vegetation, which means the loss of some plant species and the appearance of new species that had not been observed before the fire in the herbage. 
The following types of plants - Equisetum hyemale L., Sedum telephium L., Chamerion angustifolim (L.) Holub, Heracleum dissectum, Lamium album L., Sonchus arvensis L., Sonchus oleraceus L., Hemerocallis minor Mill.- can be found in the birch forests on the slopes of southern exposure on the burned areas appear in. The slopes of northern exposition are represented by Silene nutans L., Fragaria viridis Duch., Geum aleppicum Jacq., Chamerion angustifolium, Pedicularis incinata, Galeopsis bifida Boenn., Sonchus oleraceus. Among the new species on the slopes of the eastern exposures are Milium effusum L., Ranunculus repens L., Cannabis sativa L., Filipendula ulmaria (L.) Maxim., Agrimonia pilosa Ledeb., Epilobium montanum L., Chamerion angustifolium, Leucanthemum vulgare Lam., Artemisia vulgaris L., Sonchus oleraceus, Crepis sibirica, Crepis lyrata (L.) Froel., Sonchus arvensis. The slopes of the western exposures are presented by such plants as Calystegia sepium (L.) R. Br., Vicia craca L., Chamerion angustifolium, Anthriscus sylvestris (L.) Hoffm., Polemonium caeruleum L., Pedicularis incinata, Galeopsis bifida, Lamium album, Origanum vulgare, Artemisia vulgaris, Cacalia hastata L. [6].

The total projective cover on the burns in birch forests has been reduced by $15 \%$ compared to the control, and on the slopes of western exposures - by $27 \%$. The number of weed species on burns has increased by $5 \%$ in comparison with the control and is $18 \%$ of the total number of species. This tendency is typical of the slopes of the northern, southern and eastern exposures. As for the slopes of the western exposures the number of weed species does not differ significantly from the control.

The increase in the number of weed species on the burns in birch forests occurs due to the introduction of the following species - Urtica dioica L., Sonhus oleraceus, Sonchus arvensis, Stellaria graminea L., Silene nutans, Oberna behen (L.) Ikonn., Agrimonia pilosa, Elytrigia repens (L.) Nevski. On the burns, the projective cover and the occurrence of rare and endangered species have been reduced by $1.5 \%$ compared with the control. The loss of such species as Erythronium sibiricum (Fisch. et May) Kryl., Trollius asiatica L., Dactylorhiza baltica (Klinge) Orlova, etc. is widely spread.

The burns of the first year are dominated by the following species: on the southern exposure slopes - Dactylis glomerata, Pteridium aquilinum, Chamerion angustifolium, Aegopodium podagraria; on the northern slopes - Urtica dioica, Pteridium aquilinum, Chamerion angustifolium, Aegopodium podagraria; on the slopes of the eastern exposure Urtica dioica, Aegopodium podagraria.

The burns of the second year are mainly presented by: Urtica dioica, Dactylis glomerata, Pteridium aquilinum, Chamerion angustifolium, Aegopodium podagraria - on the southern exposure slopes; Equisetum sylvaticum, Urtica dioica, Pteridium aquilinum, Chamerion angustifolium, Aegopodium podagraria - on the northern slopes of exposure; Artemisia vulgaris, Sonchus arvensis, Chamerion angustifolium - on the eastern slopes; Artemisia vulgaris, Aegopodium podagraria, Dactylis glomerata, Chamerion angustifolium, Pteridium aquilinum - on the slopes of the western exposure.

The analysis of changes in the species composition and structure of the phytocenoses of the birch forests of the Eltsovsky region after the fire has revealed that the total number of burns in the burning areas has decreased on average by $6 \%$ in comparison with the control; total projective cover - by $15 \%$; the amount of weed species - by $5 \%$. The weed and meadow species of Urtica dioica, Sonhus oleraceus, Sonchus arvensis, Stellaria graminea, Silene nutans, Oberna behen, Agrimonia pilosa, Elytrigia repens are actively introduced into the grass stand.

Botanical analysis of the stand on the burns has revealed the following trends: an increase in the number of species and the total projective cover of cereals and a decrease in the total projective cover and the number of legumes. As for the grass the situation is ambiguous. The background of the general decrease in the projective cover and the number 
of burnt-out species are foolowed by an increase in the projective cover of the following species: Aegopodium podagraria, Polygonatum odoratum, Crepis lyrata, Sonhus oleraceus, Artemisia vulgaris, Oberna behen, Glechoma hederaceae L., Dracocephalum ruyshiana L., Urtica dioica, Equisetum hyemale, Equisetum pratense Ehrh., Chamerion angustifolium, Polemonium caeruleum, Stellaria graminea, Silene nutans, Agrimonia pilosa, Elytrigia repens.

Ecological analysis has showed that burns on the slopes of southern, northern and western exposures differ from the control by lower participation of mesophytes (by an average of $7 \%$ ) and mesoxerophytes (by an average of $2.4 \%$ ). There is a more significant decrease in the proportion of mesohygrophytes (by $9 \%$ ) on the slopes of northern exposures.

The two-year analysis of changes in the species composition of the grass cover of birch forests after fires has showed that not all species respond equally to this factor. According to the reaction of grassy plants to the action of agricultural fires, the following groups of species are distinguished:

- increasing numbers on burns - Urtica dioica, Dactylis glomerata, Phleum pratense, Silene nutans, Aegopodium podagraria, Hemerocallis lilioasphodeus;

- reducing the number on burns - Trifolium lupinaster, Lathyrus gmelini Fritsch., Lathyrus pratensis, Thalictrum simplex L., Paris quadrifolia L.; $\mathrm{DC}$;

- not changing the number on burns - Origanum vulgare, Ptarmica impatiens (L.)

- appearing on burns - Pedicularis incarnata, Hamerion angustifolium;

- disappearing after fires - Platanthera bifolia (L.) Rich., Dactylorhisa baltica.

Thus, agricultural fires in the form of lowland fires have a significant impact on the species composition and grass stand of the birch forests of the Eltsovsky region, lead to a decrease in species and phytocenotic diversity, level the ecological structure of the phytocenoses, reduce the resumption of forest stand, and reduce the sustainability of forest ecosystems.

\section{References}

1. E.N. Valendik, Siberian Journal of Ecology, 3 (1) (1996)

2. V.V. Furyaev, The role of fires in the process of forest formation (Novosibirsk: Science, 1996)

3. L.I. Sukhorukova, Yu.E. Belenets, V.A. Bochkov, N.Yu. Kobrin, Tr. St. Petersburg Institute of Forestry, 1 (2) (2000)

4. Yu.N. Neshataev, Methods for the selection of plant associations (L: Publishing house of St. Petersburg State University, 1971)

5. G.G. Sokolova, A.A. Kuznetsova, Geography and environmental management of Siberia, 16 (2013)

6. G.G. Sokolova, News of the Altai State University, 3-1 (83) (2014) 